\title{
Effect of drying methods on proximate analysis and antioxidant activities of ripe and unripe fruits of Diplocyclos palmatus (L.) C. Jeffery
}

\author{
Ramya Banave Rajashekar*, Nakkarike Manjubatta Sachindra**, Naveen Shivanna*** and Leelavathi Sakriyanaik \\ Phytochemistry Lab, Department of Studies in Botany, Manasagangotri, University of Mysore, Mysore-570006, Karnataka, India \\ **Meat and Marine Sciences, Central Food Technological Research Institute, Mysore-570005, Karnataka, India \\ ***Defence Food Research Laboratory, Siddharthanagar, Mysore-570011, Karnataka, India
}

\section{Article Info}

Article history

Received 11 October 2021

Revised 27 November 2021

Accepted 29 November 2021

Published Online 30 December 2021

\section{Keywords}

Antioxidant assay

Freeze-drying

Hot-air/tray drying

Phenolic content

Proximate analysis

\begin{abstract}
Ethnopharmacology has been the mainstay of traditional medicines of the entire world and currently is being integrated into mainstream medicine. The objective of the present study was to examine the impact of two drying techniques on proximate and bioactivity assays of two stages, i.e., green and red fruits using different solvents of the selected under utilized plant, Diplocyclos palmatus (L.) C. Jeffery. The proximate, reducing power assay, hydrogen peroxide assay, nitroblue tetrazolium (NBT) assay has not been reported from the selected plant. All the experiments were carried out using standard methods with slight modifications. Proximate confirms with highest protein content from tray dried red fruit $17.55 \%$ high amount of fat $5.8 \%$ from freeze-dried red fruit and tray dried green fruit shows high moisture content 9.45\%. The most remarkable findings of this experimental study were EtOHTR Soxhlet extract have shown maximum antioxidant activity of $95.21 \pm 1.95$ with DPPH, EATR Soxhlet extract showed highest total flavonoid content with $11.9 \pm 0.5$ and similar impact for NBT assay with the highest percentage of activity $38.9 \pm 1.2$ reveals temperature with ethyl acetate as favored for green fruits. The freeze-dried temperature as favored for both the fruits with ethanolic cold maceration showed the highest TPC, RPA, and on contrary to this freeze-dried ethyl acetate Soxhlet extract of both the fruits have shown highest activity with ABTS++ $60.8 \pm 1.9$ for red and $55.3 \pm 0.3$ for green fruits. The obtained experimental data can be utilized for further evaluation of enzyme activity and toxicity assays which will be useful for the bioprospecting of traditional Medicinal plants.
\end{abstract}

\section{Introduction}

Traditional dietary guidelines, health professionals, AYUSH, Pharmacognosy literature including food and agricultural organization, insist on the quality utilization of plant-based foods for the avoidance of chronic diseases and maintaining good health. There has been extensive importance in the bioactive constituents derived from plants, which include a mass of compounds with diverse identities and mechanisms of action that could be the source of nutraceuticals. Plants are natural reservoirs of constituents consumed by living organisms reveals that are almost free from side effects and have better compatibility with the human system when compared to synthetic chemicals. Thus, plant-based products have been an integral part of nutrition and primary human healthcare from time immemorial (Venketeshwer, 2012; Bhavani, 2013; Zengina et al., 2016).

Analytical challenges exist right from the extraction, establishment of bioactivity, and characterization to the level of application as nutraceuticals. Conventionally extracts are subjected for bioactivity assays not giving much importance to the impact of extraction

Corresponding author: Dr. Leelavathi Sakriyanaik Professor, Phytochemistry Lab, Department of Studies in Botany, Manasagangotri, University of Mysore, Mysore-570006, Karnataka, India

E-mail: drsleelavathi@botany.uni-mysore.ac.in Tel.: +91-9901265575, 9538766834

Copyright () 2021 Ukaaz Publications. All rights reserved.

Email: ukaaz@yahoo.com; Website: www.ukaazpublications.com methods on bioactive constituents. However, information regarding qualitative changes that occur during extraction on phytoconstituents as well as bioactivities and suitable methods of sample preparation before extraction of herbal drugs are limited to date (Puranik et al., 2012; Devi et al., 2019).

Many reports are substantiating that phytoconstituents have been proved to be the best source of antioxidants (Monte et al., 2014; Jiménez et al., 2015). In the past years, considerable researches have demonstrated that oxidative stress is the root cause for a wide variety of human disorders (Halliwell and Gutteridge, 1984; Gelderman et al., 2007; Williams et al., 2014; Wang et al., 2017).

The present investigation is focused mainly to ensure the precise content of nutrients during bioactivity estimation of the selected fruits of $D$. palmatus is a wild less widely recognized Cucurbitaceae species. During the experimental period, chances of variations in the quality of constituents may occur, therefore, the present study is to find out the effect of temperature as quality criteria and also on bioactive potency, by subjecting the sample for proximate analysis and antioxidant assays.

Cucurbitaceae comprises about 120 genera and 775 species (Mabberley, 1997), India 31 genera and 94 species are widely distributed (Renner and Pandey, 2013) which are commonly known as squashes, gourds, melons, etc., despite large and diverse species are well known as vegetables and fruits, there is cause to wonder why some of the wild cucurbits have been largely ignored by crop 
reporting services, planners, nutritionists and others responsible for the quality and quantity of our food supply (Bates et al., 1990). The wealth of ethnopharmacological applications of many rare species has not been recognized.

D. palmatus is a wild creeper commonly found distributed in the warmer forests of India, Australia, Africa, Malaysia, and Southern regions of China, and in most parts of the world, it is still a wild and underexplored creeper. But, in many regions, though the plant is wild, there are no reports due to a lack of awareness regarding its distribution and applications. Many reports are available regarding its ethnopharmacological relevance such as fruits are used by the Australian aboriginal for skin disorder and ringworm (Packer et al., 2011), fruits are edible/consumed in a few regions of India (Tripathy et al., 2013), leaves and fruits are common vegetables in Kenya, South East Asia (Njoroge and Newton, 1994) leaves and fruits are used as a laxative, expectorant and also for the treatment of impotency, female infertility and leucorrhea (Singh and Malviya, 2006). Ethnopharmacological relevance with comprehensive documentation of $D$. palmatus has been reported by many investigators (Mosaddik et al., 2003; Kokate et al., 1993; Gupta and Wagh, 2014; Kumar and Totawar, 2015).

Enzymatic degradation and microbial contamination can be prevented by drying techniques (Harbourne et al., 2009). An exhaustive review of the literature reveals that absolutely no reports are available concerning the impact of temperature on proximate analysis as well as the bioactive composition of the selected fruits.

\section{Materials and Methods}

\subsection{Plant material}

D. palmatus (DP) is a slender, highly branched seasonal creeper with a $6 \mathrm{~m}$ long stem. Leaves simple, alternate, palmately lobed, with obnoxious odor when mashed. Flowers are unisexual, white to yellowish, female flowers solitary and male flowers in small fascicles. It flowers from August to September. Fruit green with white longitudinal stripes, which turn out to be intensely red with ripeness (Sanbi.org/resource/Infobase). The samples of the unripe green and ripe red fruits of DP were collected, identified, and authenticated. The Voucher Specimen (UOMBOT19DP1) was deposited in the herbarium of the Department of Studies in Botany Manasagangotri, Mysore. The unripe (green) and ripened (red) fruits were separated, washed thoroughly with distilled water, and surface dried with the muslin cloth.

\subsection{Physical measurement of fruits}

The fruit length and size were taken using a vernier caliper MITUTOYO in/mm Lcd Digital Electronic Carbon Fiber Vernier Caliper Gauge Micrometer (Figures 1 and 2).

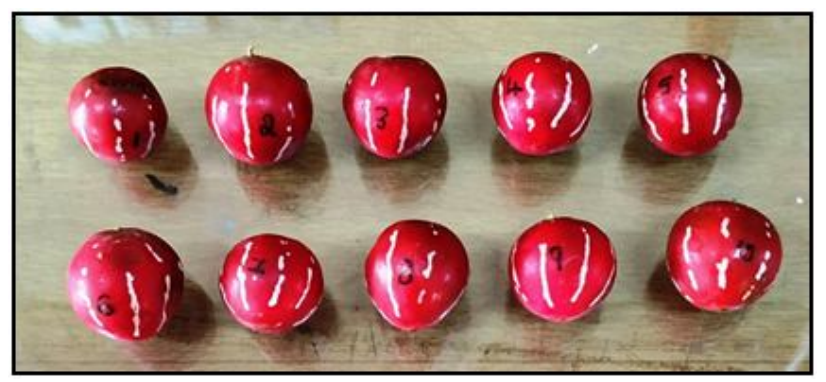

Figure 1: Ripe red fruits.

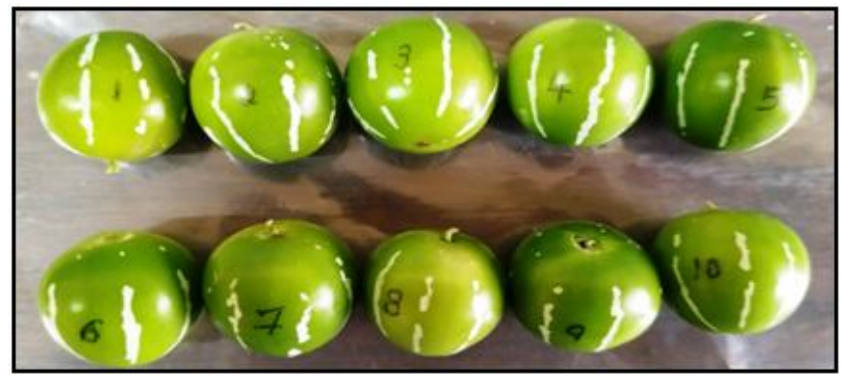

Figure 2: Unripe green fruits.

\subsection{Estimation of $\mathrm{pH}$ and brix}

As a prerequisite $\mathrm{pH}$ was determined, $10 \mathrm{ml}$ of both the green and red fresh fruit extracts were taken in two beakers and the $\mathrm{pH}$ meter was calibrated with phosphate buffer of $\mathrm{pH} 4.0$ and 7.0, then the probe was immersed into the extracts and the readings were recorded. Estimation of ${ }^{\circ} \mathrm{Brix}$ (Total soluble solids) using a HI96801 refractometer ( 0 to $85 \%{ }^{\circ}$ Brix $/ 0$ to $80 \mathrm{dC}$ (32 to $176 \mathrm{dF}$ ) (Horwitz and Latimer 2006; Nonga, 2014). The refractometer was standardized with distilled water at 0 , then the samples were placed and readings were recorded.

\subsection{Preparation of samples}

The cleaned fresh succulent fruits were subjected to two different drying processes to study the impact on proximate as well as bioactivity.

\subsection{Hot air/tray drying method}

The cleaned fruits were sliced to make uniform-sized slices (Figures 3 and 4), then spread onto a clean tray for proper drying using a dryer (Drying model 024 E, Kilburn, and a company limited, Bombay-1) (Sun et al., 2015). To decide the best suitable temperature for drying, samples were first subjected to different temperatures, and then it was subjected at $50{ }^{\circ} \mathrm{C} 2 \mathrm{~m} / \mathrm{s}$ air flow rate and $45 \%$ relative humidity for $10 \mathrm{~h}$. After drying, samples were ground with a blade mixture, and the size of powder varied from 0 to $0.63 \mathrm{~mm}$, the powders were stored in zip lock covers and stored in desiccators until further use. These samples were named as TR for tray dried red fruits, TG for tray dried green fruits.

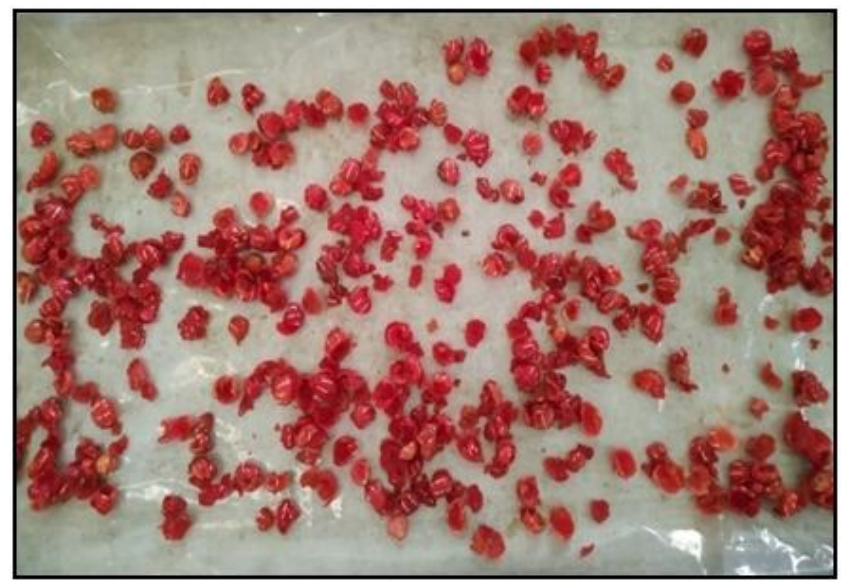

Figure 3: Tray dried red fruits. 


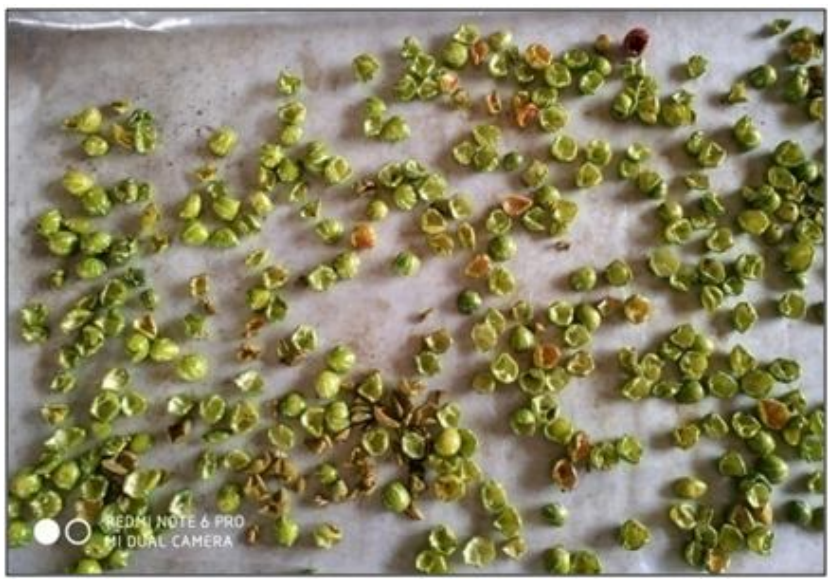

Figure 4: Tray dried green fruits.

\subsection{Freeze-drying method}

Sliced fruits (Figure 5) were subjected to freeze-dry at $-85^{\circ} \mathrm{C}$ and for $12 \mathrm{~h}$ using a Laboratory freeze dryer (GAMMA 2-16 LSC plus Germany), (Hossain et al., 2010). After drying, samples were ground with a blade mixture and stored at desiccators, and the size of powder varied from 0 to $0.63 \mathrm{~mm}$, the powders were stored in zip lock covers until further use. These samples were named FR freeze-dried red fruits, FG for freeze-dried green fruits.

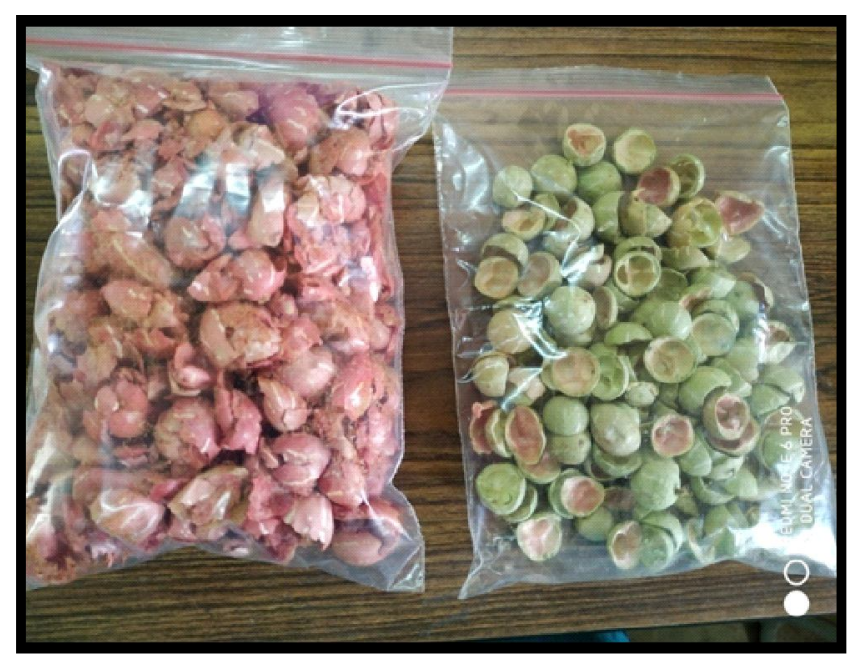

Figure 5: Freeze dried red and green fruits.

\subsection{Proximate analysis}

The parameters include moisture, crude protein, ash, crude fat; and carbohydrate, color all of these were carried out by the methods (Horwitz and Latimer, AOAC 2006).

\subsection{Moisture}

Moisture content in the sample was determined by using a hot air oven (Drying model 024 E, Kilburn and company limited, Bombay-1). To a previously weighed clean empty Petri dish add approximately $5 \mathrm{~g}$ of the sample and spread on the Perti dish homogeneously. The sample was heated at the temperature of $110^{\circ} \mathrm{C}$ for 5-6 h until a stable weight was achieved. Moisture percentage was obtained from the weight loss due to heating.
$\%$ of Moisture $=($ Initial weight of sample - weight after drying $)$ $\times 100 /$ Initial weight of the sample.

\subsection{Total crude protein}

The crude protein of the fruit extracts was represented by measuring the nitrogen $(\mathrm{N})$ content. This determination was done based on the standard. Briefly, $0.5 \mathrm{~g}$ of sample was placed in a Kjeldahl flask. Subsequently, $2 \mathrm{~g}$ of catalyst mixture (10 parts $\mathrm{K}_{2} \mathrm{SO}_{4}$ to one part of $\mathrm{CuSO}_{4}$ ) and $25 \mathrm{ml}$ of concentrated $\mathrm{H}_{2} \mathrm{SO}_{4}$ were added into the Kjeldahl flask. All the components were mixed thoroughly and heated until the mixture became clear. Wash the flask with distilled water and swirl to mix. Transfer the digest to a $250 \mathrm{ml}$ volumetric flask using a funnel. Measure approximately $15 \mathrm{ml}$ of $2 \%$ of boric acid solution into the conical flask with a mixed indicator of 2-3 drops (10 $\mathrm{ml}$ of $0.1 \mathrm{ml}$ bromocresol green and $2 \mathrm{ml}$ of methyl red) in a $150 \mathrm{ml}$ conical flask to the distillation assembly using a pipette. Add a small amount of distilled water and then add $20 \mathrm{ml}$ of $\mathrm{NaOH}$ connect steam to distillation assembly. Distillation was done within 10 min and then the produced $\mathrm{NH}_{3}$ was collected (in the form of $\mathrm{NH}_{4} \mathrm{OH}$ ) in the conical flask was determined by titrating with N/70 HCL. The amount of total nitrogen and crude protein was calculated by using the formula:

Crude protein content $(\%)=\%$ of Nitrogen $\times 6.25$

\subsection{Total ash}

An empty crucible was accurately weighed, and approximately 0.5-1.0 $\mathrm{g}$ of samples were weighed in it using a weighing balance. The sample in the crucible was charred with Bunsen burner, then placed in a muffle furnace at $550^{\circ} \mathrm{C}$ for more than $5 \mathrm{~h}$ until the ash completely turn to white ash, then crucible was carefully removed from the furnace to a dissector to cool, and then weighed.

\subsection{Crude fat}

The crude fat content of samples was determined by the Soxhlet unit. About $1 \mathrm{~g}$ of moisture-free sample was tied with a whatmann filter paper, placed in a soxhlet extraction unit. Extraction was continued for $8 \mathrm{~h}$ using petroleum ether as a solvent, after the extraction the pre-weighed round bottom flask containing the extracted fat was dried on a water bath at $98^{\circ} \mathrm{C} \pm 5^{\circ} \mathrm{C}$. After complete drying, the round bottom flask was cooled in desiccators and the weight was recorded. The percentage of crude fat was calculated by the differences in the initial and final weight of the round bottom flask on a wet weight basis.

\subsection{Carbohydrates}

The value of total carbohydrate was obtained by $=100-($ Percentage of protein + ash + fat + fiber).

\subsection{Color measurement}

Color measurement was made by using a lab scan XE spectrophotometer (Hunter Lab scans XE, USA) and it was calibrated to white and black standard sites of samples. The tristimulus $\mathrm{L}^{*} \mathrm{a}^{*} \mathrm{~b}^{*}$ measurement model was used as it relates to the human eye response to color. The $\mathrm{L}^{*}$ variable lightness $\left(\mathrm{L}^{*}=0\right.$ for black, $\mathrm{L}^{*}=100$ for white), a* scale represents the red/green. (+a* intensity in red and $-\mathrm{a}^{*}$ intensity in green) and the $\mathrm{b}^{*}$ scale represents the yellow/blue $\left(+b^{*}\right.$ intensity in yellow and $-a^{*}$ intensity in blue). The fruit samples were filled into a clear Petri dish and transmittance readings were taken further triplicate readings were taken for each sample. 


\subsection{Preparation of solvent extracts}

The fruit samples of both tray dried and freeze-dried (Red and Green) were taken for two different methods of extraction using three different solvents, viz., methanolic freeze-dried red fruits (MFR), methanolic freeze-dried green fruits (MFG), ethanolic freezedried red fruits (EtOHFR), ethanolic freeze-dried green fruits (EtOHFG), ethlyacetate freeze-dried red fruits (EAFR), ethlyacetate freeze-dried green fruits (EAFG). Methanolic tray dried red fruits (MTR), methanolic tray dried green fruits (MTG), ethanol tray dried red fruits (EtOHTR), ethanol tray dried green fruits (EtOHTG), ethlyacetate tray dried red fruits (EATR), ethlyacetate tray green fruits (EATG), extractions were carried out according to Harborne 1973.

\subsection{Soxhlet extraction}

Hot continuous extraction: The finely ground crude powder is placed in a porous bag or "thimble" which is placed in the Soxhlet apparatus. The extracting solvent in the flask is heated and the vapors condense in a condenser. The condensed extract drips into the thimble containing the crude drug when the level of the liquid chamber rises to the top of the siphon tube, the liquid contents of the chamber siphon into the flask. This process is continuous ( 6 to $8 \mathrm{~h}$ ) and is carried out until a drop of solvent from the siphon tube does not leave the residue when evaporated. Then filter the extracts to allow drying with a flask evaporator then stored them at $4^{\circ} \mathrm{C}$ for further analysis.

\subsection{Cold maceration}

Around $5 \mathrm{~g}$ of dried fruit sample was taken into a conical flask and a known volume of solvent was added, kept for extraction in a rotary shaker (Thermo scientific model MAXQ 4000 ) at $37^{\circ} \mathrm{C}$ temperature, 150-200 rpm for $24 \mathrm{~h}$. Then filtered extracts were dried then stored at $4^{\circ} \mathrm{C}$ for further experiments.

\subsection{Percentage yield}

The dried fruit powder was subjected to both extraction methods (Soxhlet and maceration), after the completion of extraction, the solvent extracts were allowed to evaporate at room temperature to get dry material. The percentage of yield was calculated by using the following formula:

$$
\% \text { of Yield }(\mathrm{g} / 100 \mathrm{~g})=(\mathrm{W} 1 / \mathrm{W} 2) \times 100
$$

W1- Weight of the dried extract, W2- Weight of the initial dried fruit sample.

\subsection{Estimation of total phenolic content (TPC)}

The TPC was determined using Folin-Ciocalteu (FC) reagent according to the method with slight modification (Singleton and Rossi, 1965). Briefly, $10 \mu \mathrm{l}$ of extract from $(10 \mathrm{mg} / \mathrm{ml})$ was mixed with $200 \mu \mathrm{l}$ of FC reagent (1:10 folds) and incubated for $5 \mathrm{~min}$ at room temperature then $25 \mu 1$ of $10 \%$ of sodium bicarbonate solution was and incubate at $37^{\circ} \mathrm{C}$ for $30 \mathrm{~min}$, the absorbance was measured at $765 \mathrm{~nm}$. The TPC was evaluated from the gallic acid standard curve (GAE $\mu \mathrm{g} / \mathrm{mg})$.

\subsection{Estimation of total flavonoid content (TFC)}

The TFC was determined by the method with slight modification (Sakanaka et al., 2005) Fruit extracts $(50 \mu \mathrm{l})$ of each solvent was taken separately and add distilled water to make the volume $0.5 \mathrm{ml}$ followed by the inclusion of $75 \mu 1$ of $5 \%$ (w/v) sodium nitrite solution and incubate for about $6 \mathrm{~min}$ using water bath at $37^{\circ} \mathrm{C}$, followed by addition of $150 \mu \mathrm{l}$ of $10 \%$ (w/v) $\mathrm{AlCl}_{3}$ and again incubate for $5 \mathrm{~min}$ at room temperature and finally add $0.5 \mathrm{mlof} 1 \mathrm{M} \mathrm{NaOH}$, and addition of $100 \mu$ ldistilled water to make up the volume to $2 \mathrm{ml}$, the absorbance was measured at $415 \mathrm{~nm}$. The total flavonoid content was evaluated using ( $\mathrm{RE} \mu \mathrm{g} / \mathrm{mg}$ ) rutin standard curve $(0.8$ $\mathrm{mg} / \mathrm{ml})$ stock.

\subsection{Antioxidant assays}

Each extract was dissolved in respective solvents (methanol, ethanol, and ethyl acetate) to make a stock of $10 \mathrm{mg} / \mathrm{ml}(10,000$ micrograms) from this required concentration used for assays. All the chemicals and reagents were used are laboratory grade, and reference chemicals were used for comparison in a few assays.

\subsection{DPPH free radical scavenging activity (2, 2-diphenly-1- picrylhydrazyl)}

The DPPH assay of the extract was followed according to the method with slight modification (Brand-Williams et al., 1995). By dissolving $6.3 \mathrm{mg}$ DPPH in $100 \mathrm{ml}$ methanol, the stock was prepared kept in a refrigerator until additional use. $10 \mu \mathrm{l}$ (Concentration $100 \mu \mathrm{g} / \mathrm{ml}$ ) of the extract was mixed with $100 \mu$ of DPPH solution in a 96 well plate. The plate was incubated at $37^{\circ} \mathrm{C}$ for $60 \mathrm{~min}$, and then read the absorbance at $517 \mathrm{~nm}$. The percent of antioxidant or radical scavenging activity was calculated using the following formula:

$$
\% \text { Antioxidant activity }=[(\mathrm{Ac}-\mathrm{As}) / \mathrm{Ac}] \times 100
$$

where, Ac and As is the absorbance of control and sample, respectively. The control consists of $100 \mu 1$ methanol in the position of plant samples.

\subsection{2 $\mathrm{ABTS}^{++}$radical scavenging assay (2, 2-azino-bis (3- ethlybenzothiazoline-6-sulfonic acid)}

$\mathrm{ABTS}^{++}$radical scavenging activity was carried out using the method (Sachindra et al., 2010) with slight modification. ABTS radical solution was prepared by mixing $5 \mathrm{ml}$ of ready-to-use $\mathrm{ABTS}^{++}$solution with $100 \mathrm{ml}$ of acetate buffer $(0.05 \mathrm{M}, \mathrm{pH} 4.5)$ and 5 units of peroxidase and incubating at $37^{\circ} \mathrm{C}$ for $15 \mathrm{~h}$. The decolorization of the $\mathrm{ABTS}^{++}$ radical solution was started by mixing $1.9 \mathrm{ml}$ of $\mathrm{ABTS}^{++}$solution with $15 \mu \mathrm{l}$ (concentraion $150 \mu \mathrm{g} / \mathrm{ml}$ ) of sample and incubating at $37^{\circ} \mathrm{C}$ for $1 \mathrm{~h}$. The absorbance was measured at $734 \mathrm{~nm}$. Scavenging activity (SA) \% was calculated as follows:

SA, $\%=[1-($ As sample - As sample blank $) /$ A control $] \times 100$

\subsection{Hydrogen peroxide scavenging assay}

The activity was determined by the following method (Ruch et al., 1989 ) with minor modification. An aliquot of $0.6 \mathrm{ml}$ of methanol for control and $50 \mu \mathrm{l}$ (concentration $500 \mu \mathrm{g} / \mathrm{ml}$ ) of different solvent extracts and made up to $0.6 \mathrm{ml}$ with methanol, then add $0.6 \mathrm{ml} 40$ $\mathrm{mM} \mathrm{H} \mathrm{O}_{2}$ and $\mathrm{PO}_{4}$ buffer incubate for $10 \mathrm{~min}$ at room temperature and read the absorbance at $230 \mathrm{~nm}$. The blank solution contains $\mathrm{Na}_{3} \mathrm{Po}_{4}$ buffer without $\mathrm{H}_{2} \mathrm{O}_{2}$. The scavenging of $\mathrm{H}_{2} \mathrm{O}_{2}(\mathrm{mM})$ in the assay was calculated using the following formula.

$\mathrm{H}_{2} \mathrm{O}_{2}$ Scavenging effect $(\%)=[(\mathrm{A} 0-\mathrm{A} 1) / \mathrm{A} 0 \times 100]$

$\mathrm{A} 0=$ Absorbance of control, $\mathrm{A} 1=$ Absorbance of the sample. 
2.24 Superoxide anion radical scavenging activity (Nitroblue tetrazolium)

The assay was done based on the reduction of NBT in the presence of NADH and phenazine methosulfate according to the method prescribed by (Chou et al., 2009) with slight modification. The reaction mixture contains $100 \mu \mathrm{l}$ of $(156 \mu \mathrm{M}) \mathrm{NBT}, 100 \mu \mathrm{l}$ of (468 $\mu \mathrm{M}) \mathrm{NADH}$, and $10 \mu \mathrm{l}$ of extract. The reaction was commenced by adding up to $10 \mu \mathrm{l}$ of $(60 \mu \mathrm{M})$ phenazine methosulfate. All the reagents were prepared by using $(0.1 \mathrm{M}, \mathrm{pH} 8.0)$ and the absorbance was recorded at $560 \mathrm{~nm}$ after 5 min incubation at room temperature. Percentage of inhibition was calculated against a control that contains all the reagent, and $\mathrm{PO}_{4}$ buffer in place of the sample. To diminish in absorbance with plant extract and the reference compound illustrate their competence to quench superoxide radicals in the reaction mixture.

$\%$ of Scavenging activity $=[(\mathrm{Ac}-\mathrm{As}) / \mathrm{Ac}] \times 100$

\subsection{Reducing potential assay}

The reducing power of all the extracts was determined according to the method developed by (Oyaizu, 1986) with a small alteration. A $50 \mu \mathrm{l}$ of each extract was mixed with $150 \mu \mathrm{l}$ of $(0.2 \mathrm{M}, \mathrm{pH} 6.6)$ and $200 \mu 1$ of $\mathrm{K}_{4}\left[\mathrm{Fe}(\mathrm{CN})_{6}\right] .3 \mathrm{H}_{2} \mathrm{O}(1 \%$, w/v) was added, mixed well, and incubated in a water bath for $20 \mathrm{~min}$ at $50^{\circ} \mathrm{C}$. Then $200 \mu \mathrm{l}$ of trichloroacetic acid $(10 \% \mathrm{w} / \mathrm{v}$ in distilled water) was added and centrifuged at $8000 \mathrm{rpm}$ for $10 \mathrm{~min}$, and its $0.5 \mathrm{ml}$ of supernatant was mixed with the corresponding volume of distilled water and 94 $\mu 1$ of $0.1 \% \mathrm{Fecl}_{3}$. It was further incubated at $20^{\circ} \mathrm{C}$ for $10 \mathrm{~min}$ and absorbance was read at $700 \mathrm{~nm}$. The reducing potential of the sample was indicated as the variation in optical density from control as well as test, the highest the degree of absorbance the stronger the reducing power.

\subsection{Statistical analysis}

All experiments were carried out in triplicates $(n=3)$ and the results were expressed as mean values and standard error (SE). The differences between the tested extracts were analyzed using oneway analysis of variance (ANOVA) followed by Turkey's honestly significant difference post hoc test with $p>0.05$. This treatment was carried out using SPSS v.14.0 program.

\section{Results}

\subsection{Physical parameters}

The obtained results of all the physical parameters were represented in Table 1. The size of the selected fruit's height, weight, and width was not significantly different. However, ripe red fruits measured slightly higher values $(18.26 \pm 1.27)$ over unripe green fruits (17.91 \pm 0.73 ). There was a significant difference in ${ }^{\circ}$ Brix value, the red fruit showed a higher value with 5.4 , whereas a decline was noticed in green fruits with 2.1. The fruits with different colors after subjecting to different temperatures did not show any significant variations in the expression of color in powdered form. However, the green fruit showed slightly more lightness and yellowness compared to red fruits, redness was more towards red fruits.

Tray-dried and Freeze-dried both green and red fruits were analyzed for moisture, protein, ash, crude fat and carbohydrate content were given in Table 2. Tray-dried both the fruit samples exhibited almost similar percentage of moisture contents, but the Freeze-dried fruits showed little variation, the red fruits had retained moisture of 6.01 \pm 0.56 , and green fruits showed $4.20 \pm 0.25$ which is much low when compared with tray dried fruits. There was a difference in crude protein content between tray dried and freeze-dried, the highest percentage was observed in tray dried red fruits followed by freeze-dried $17.55 \pm 0.48$ and $14.79 \pm 0.06$, respectively. Green fruits showed little higher in freeze-dried with $9.75 \pm 0.04$, whereas lowest recorded in tray dried with $2.11 \pm 0.09$, indicating ripe fruits tray dried have more percentage of crude protein content. The result shows freeze-dried green fruits recorded the highest ash content $(13.1 \pm 0.41)$ and tray dried with low ash content $(6.02 \pm$ $0.87)$.

Table 1: Physical parameters of both red and green fruits of D. palmatus

\begin{tabular}{|l|c|c|}
\hline Variable & Red & Green \\
\hline Height $(\mathrm{mm})$ & $18.26 \pm 1.27$ & $17.91 \pm 0.73$ \\
Weight $(\mathrm{g})$ & $3.26 \pm 0.37$ & $2.99 \pm 0.267$ \\
Width $(\mathrm{mm})$ & $18.44 \pm 0.70$ & $17.69 \pm 0.464$ \\
$\mathrm{pH}$ & $6.13 \pm 0.0058$ & $5.643 \pm 0.00578$ \\
${ }^{\circ}$ Brix & 5.4 & 2.1 \\
Color & & \\
L*(lightness) & 43.69 & 44.33 \\
$\mathrm{a} *$ (redness) & 4.04 & -1.16 \\
$\mathrm{~b} *$ (yellowness) & 12.96 & 18.45 \\
\hline
\end{tabular}

Each value is the average of triplicate measurements. L-lightness (100, white; 0 , black), a: redness (-, green; +, red), b: yellowness (-, blue; + , yellowness).

\subsection{Yield}

The highest yield (Table 3) was obtained from freeze-dried red fruits of methanolic Soxhlet extracts, and the lowest values were obtained from tray dried green fruits of ethyl acetate cold extracts.

\subsection{Total phenolic content}

The total phenolic content (TPC), in the present study, recorded the highest concentration from EtOHFR cold macerated fruits with $21.6 \pm 0.17$, followed by EtOHFG cold macerated with $19.5 \pm 0.17$, indicated that both red and green fruits have retained phenolic contents under freeze-dried temperature (Figure 6). The lowest concentration recorded was EATG Soxhlet extracted with $12.2 \pm$ 0.06 . Phenolic compounds are treated to be the primary antioxidants because they are the chain-breaking molecules that react with free radicals to stabilize them.

\subsection{Total flavonoid content}

Total flavonoid concentration (TFC) was noted highest from EATR Soxhlet extracts with $11.9 \pm 0.5$ and EtOHTR Soxhlet with $11.3 \pm$ 0.2 . The lowest concentration was recorded from MFG cold extracts with $1.1 \pm 0.1$ which is indicative that fully ripe fruits have a high concentration of flavonoids (Figure 7).

\subsection{Antioxidant assay by DPPH}

The obtained experimental results of both TPC and TFC have been further approved for their biological activity when assessed for antioxidant assay with DPPH. Both EtOHTR and EtOHFR Soxhlet 
extracts have shown the highest percentage of antioxidant activity with $95.21 \pm 1.95$ and $93.63 \pm 0.05$ respectively, (Figure 8 ). The lowest recorded was $12.12 \pm 4.92$ from the EAFR cold extracts; reveals that red fruits have maximum antioxidant potency in both the temperature indicating temperature favored for the release of bound form of phenolics enhanced the reactivity. Phytoconstituents of plants have antioxidant properties which can prevent various biochemical processes.

Table 2: Proximate analysis red and green fruits of $D$. palmatus

\begin{tabular}{|l|c|c|c|c|c|}
\hline Sample & $\begin{array}{c}\text { Moisture (\%) } \\
(\%) \mathbf{N \times 6 . 2 5})\end{array}$ & Crude protein & Ash (\%) & $\begin{array}{c}\text { Crude } \\
\text { fat }(\%)\end{array}$ & $\begin{array}{c}\text { Carbohydrates } \\
(\%)\end{array}$ \\
\hline Red fruit (TD) & $9.40 \pm 0.28$ & $17.55 \pm 0.483$ & $8.02 \pm 0.32$ & $3.19 \pm 0.01$ & $61.72 \pm 0.16$ \\
Green fruit (TD) & $9.45 \pm 0.32$ & $2.11 \pm 0.098658$ & $6.02 \pm 0.87$ & $2.69 \pm 0.11$ & $79.41 \pm 0.28$ \\
Red fruit (FD) & $6.01 \pm 0.56$ & $14.79 \pm 0.064$ & $12.9 \pm 0.1$ & $5.8 \pm 0.06$ & $60.37 \pm 0.11$ \\
Green fruit (FD) & $4.20 \pm 0.25$ & $9.75 \pm 0.043589$ & $13.1 \pm 0.41$ & $2.9 \pm 0.064$ & $70.03 \pm 0.02$ \\
\hline
\end{tabular}

The standard deviation for three replicate $(n=3)$ determinations $\mathrm{TD}=$ Tray dry $\mathrm{FD}=$ Freeze dry; GF-Green fruit, RF- Red fruit.

Table 3: Percentage yield of both TD and FD DP fruits powder with cold and Soxhlet extraction using different solvents

\begin{tabular}{|l|c|c|c|c|c|c|c|c|}
\hline & \multicolumn{2}{|c|}{ TD (Cold) } & \multicolumn{2}{c|}{ TD (Soxhlet) } & \multicolumn{3}{c|}{ FD (Cold) } & \multicolumn{1}{c|}{ FD (Soxhlet) } \\
\hline Extracts & GF & RF & GF & RF & \multicolumn{1}{c|}{ GF } & RF & GF & RF \\
\hline Methanol & $32.87 \pm 0.13$ & $22.14 \pm 0.01$ & $31.11 \pm 0.02$ & $22.56 \pm 0.015$ & $14.89 \pm 0.006$ & $15.96 \pm 0.01$ & $34.68 \pm 0.01$ & $35.25 \pm 0.015$ \\
Ethanol & $5.592 \pm 0.01$ & $7.04 \pm 0.006$ & $17.55 \pm 0.01$ & $17.695 \pm 0.015$ & $5.263 \pm 0.001$ & $6.68 \pm 0.005$ & $5.72 \pm 0.006$ & $19.17 \pm 0.006$ \\
Ethyl acetate & $1.52 \pm 0.01$ & $2.23 \pm 0.012$ & $3.12 \pm 0.017$ & $4.08 \pm 0.012$ & $1.97 \pm 0.012$ & $2.16 \pm 0.005$ & $2.239 \pm 0.00$ & $18.99 \pm 0.012$ \\
\hline
\end{tabular}

The value expressed are means \pm SD of three measurements.TD $=$ Tray dry FD = Freeze dry; GF-Green fruit, RF- Red fruit.

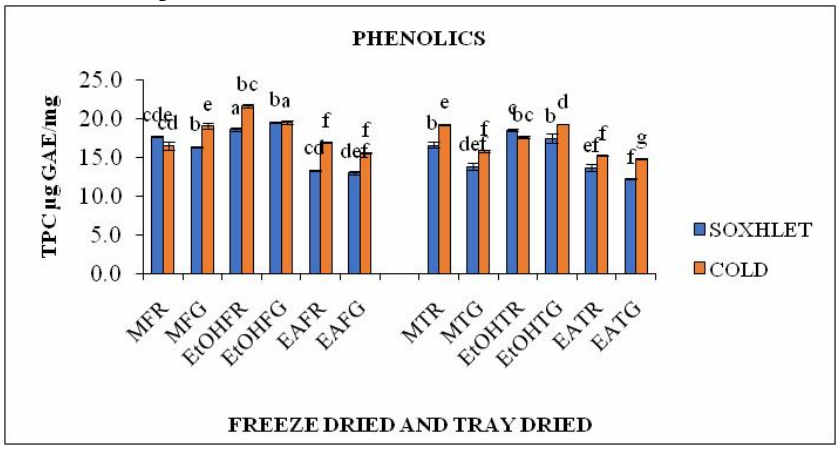

Figure 6: Total phenolic content of $D$. palmatus fruit extracts. Values are means of \pm standard error of triplicate samples. Mean values bearing different superscripts (a-g) in the same column and row differ significantly $(p<0.05)$. M-Methanol, EtOH-Ethanol, EA-Ethyl acetate, F-Freeze dried, T-Tray dried, R-Red fruit, G-Green fruit.

\subsection{ABTS++ radical scavenging assay}

This particular assay is to find out the total antioxidant activity about the extract and it was observed that both the EAFR and EAFG Soxhlet extractions exhibited maximum activity with $60.88 \pm 1.9$ and $55.3 \pm 0.3$, respectively, lowest activity recorded from MTG cold macerated with $4.2 \pm 0.8$, indicating low temperature has not favored for the release of radical scavenging phytoconstituents (Figure 9).

\subsection{Reducing power assay}

Reducing power activity of compounds specify that they can donate an electron and without difficulty reduce the oxidized intermediates of lipid peroxidases, thus phytoconstituents act as strong antioxidants. The highest reducing potentiality has been recorded from the EtOHFG cold macerated with $1.5 \pm 0.001$, followed by similar potency from MFG Soxhlet extract and EAFR cold macerated with $1.3 \pm 0.021$ and $1.3 \pm 0.014$, respectively (Figure 10).

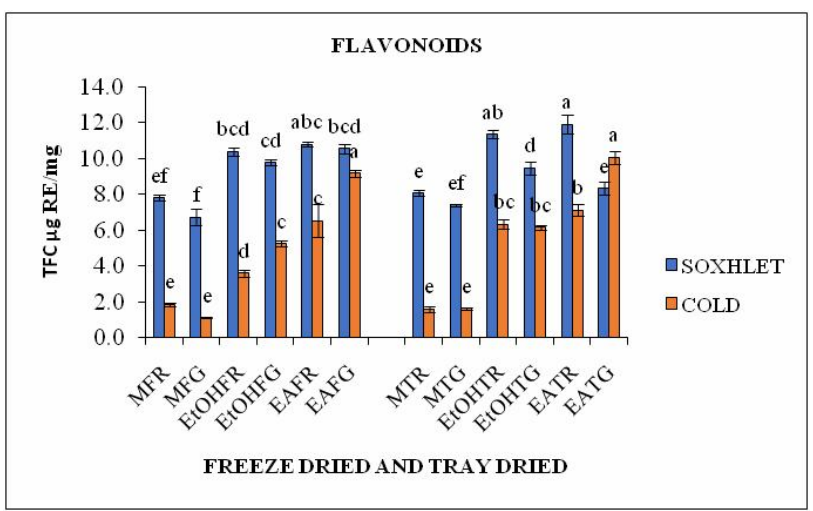

Figure 7: Total flavonoid content of D.palmatus fruit extracts. Values are means of \pm standard error of triplicate samples. Mean values bearing different superscripts (a-f) in the same column and row differ significantly $(p<0.05)$. M-methanol, EtOH-ethanol, EA-ethyl acetate, F-freeze dried, T-tray dried, R-red fruit, Ggreen fruit.

\subsection{Hydrogen peroxide assay}

While dealing with reactive oxygen species, according to literature singlet oxygen or hydroxyl ions cannot cross the cell membranes but hydrogen peroxide can easily cross the membranes, thus it is an essential parameter to be evaluated. The obtained result is indicative that EAFG and EAFR Soxhlet have shown highest percentage with $99.8 \pm 0.02$ and $99.2 \pm 0.023$ (Figure 11). Thus, both the fruits have exhibited the highest scavenging activities, lowest recorded is somewhat difficult to assess with a $2.1 \pm 0.07$ from MFR cold 
macerated, may be both freeze-dried and cold maceration has not favored for the release of important compounds.

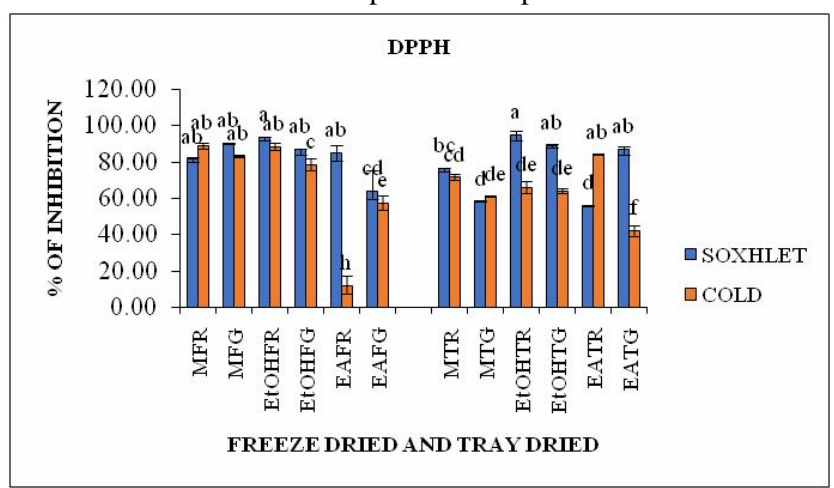

Figure 8: DPPH assay of $D$. palmatus fruit extracts. Values are means of \pm standard error of triplicate samples. Mean values bearing different superscripts (a-h) in the same column and row differ significantly $(p<0.05)$. M-methanol, EtOH-ethanol, EA-ethyl acetate, F-freeze dried, T-tray dried, R-red fruit, Ggreen fruit.

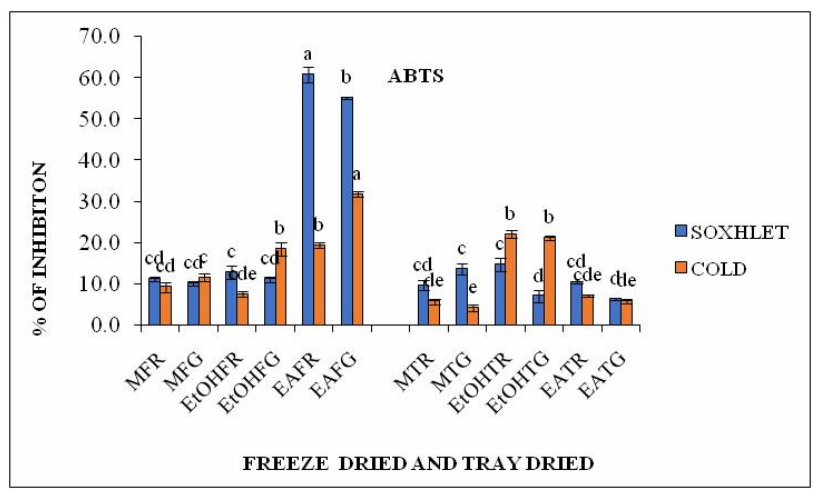

Figure 9: ABTS assay of $D$. palmatus fruit extracts. Values are means of \pm standard error of triplicate samples. Mean values bearing different superscripts (a-e) in the same column and row differ significantly $(p<0.05)$. Mmethanol, EtOH-ethanol, EA-ethyl acetate, F-freeze dried, T-tray dried, R-Red fruit, G-green fruit.

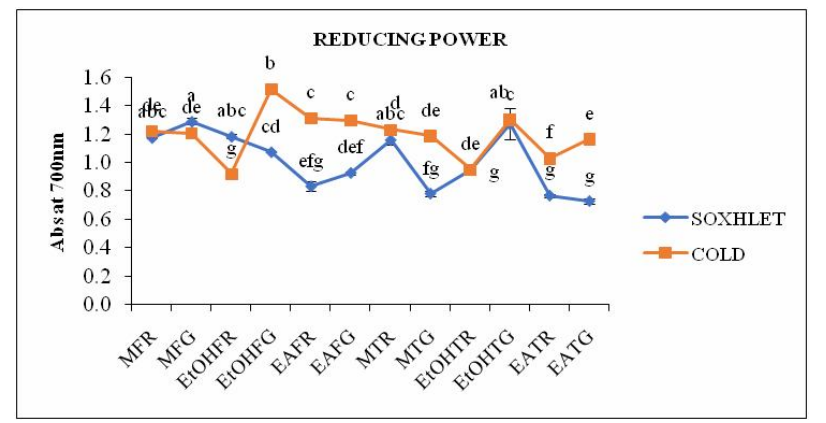

Figure10: Reducing power assay of D.palmatus fruit extracts. Values are means of \pm standard error of triplicate samples. Mean values bearing different superscripts (a-g) in the same column and row differ significantly $(p<0.05)$. M-methanol, EtOH-ethanol, EA-ethyl acetate, F-freeze dried, T-tray dried, R-red fruit, Ggreen fruit.

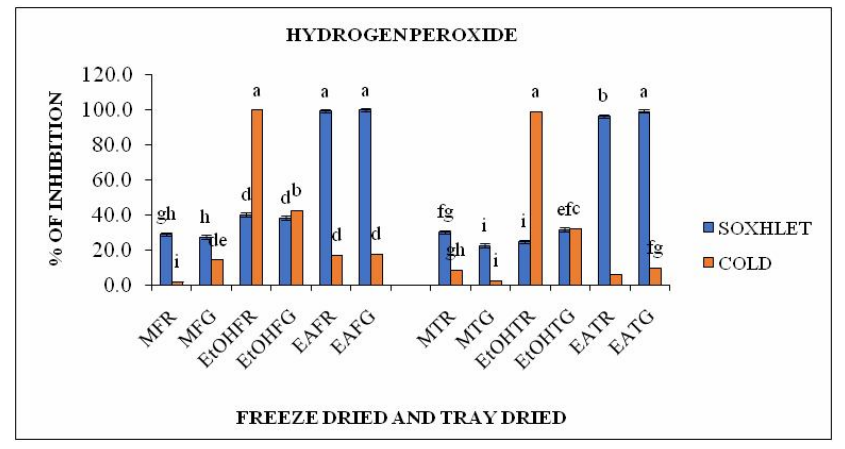

Figure 11:Hydrogen peroxide assay of D.palmatus fruit extracts. Values are means of \pm standard error of triplicate samples. Mean values bearing different superscripts (a-i) in the same column and row differ significantly $(p<0.05)$. M-methanol, EtOH-ethanol, EA-ethyl acetate; F-freeze dried, T-tray dried, R-red fruit, GGreen fruit.

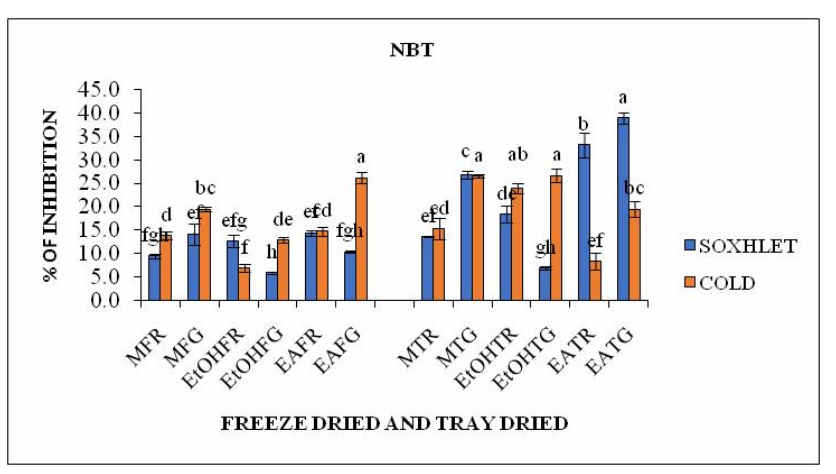

Figure 12: NBT assay of D. palmatus fruit extracts. Values are means of \pm standard error of triplicate samples. Mean values bearing different superscripts (a-h) in the same column and row differ significantly $(p<0.05)$. M-methanol, EtOH-ethanol, EA-ethyl acetate; Ffreeze dried, T-tray dried, R-red fruit, G-green fruit.

\subsection{NBT assay}

The present experimental results recorded showed the highest activity from EATG soxhlet extract with $38.9 \pm 1.2$ followed by $33.2 \pm 2.6$ from the similar treatment of EATR indicating that temperature has an impact for the scavenging activity, the lowest recorded is from EtOHFG soxhlet extract with 5.9 \pm 0.2 and EtOHFR cold macerated with $6.9 \pm 0.8$ (Figure 12). Overall Green fruits have retained a stable activity with $26.2 \pm 1.1$ to $26.6 \pm 0.4$ with ethanol, methanol, and ethyl acetate cold macerated extracts has shown an intermediate antioxidant capacity for NBT analysis.

\section{Discussion}

The present results revealed the slight variations between the two fruits are a natural process as the fruit has attained its maximum size with its physiological developmental processes; a similar opinion has been reported (Hayat et al., 2014). The succulent fresh red fruits showed higher $\mathrm{pH} 6.13 \pm 0.005$ when compared with raw green fruits with a value of $5.6 \pm 0.005$ showing slightly towards alkaline nature but both are not significantly different, during the process of development accumulation of pigments and enzymatic conversions naturally contribute to the increase in ${ }^{\circ} \mathrm{Brix}$ 
value (Purvis, 1993; Gil et al., 2002). There is a marginal difference between $\mathrm{pH}$ and ${ }^{\circ} \mathrm{Brix}$ of ripe red fruits is an important property utilized for nutritional labeling and food quality (Marielli et al., 2015).

The moisture content of any food product is an index of its waterholding activity (Frazier and Westhoff, 1978) and is used as a measure of stability and susceptibility to microbial contamination (Davey,1989), extremely lower than the range value of some Nigerian pumpkins (Cucurbit species) seeds has been reported (Blessing, 2011). The high amount of moisture is also disadvantageous leads to spoilage (Desai and Salunkhe, 1991).

Nutritional proteins play a significant role in synthesis in addition to the maintenance of tissues, enzymes, and hormones required for healthy functioning (Hayat et al., 2014). Food manufacturing factories are primarily focusing on finding new raw materials to obtain the superior quality of that product (Ambawat and Khetarpaul, 2018). The cabinet dry was found to be the best method of drying for retention of phytochemicals (Thorat et al., 2018).

Fruits are generally not an extremely superior source of fats and are generally suggested as an element of a weight-reducing diet. The crude fat in the present study highest percentage recorded from freeze-dried red fruits with $5.8 \%$ and lowest from tray dried green fruits with $2.82 \%$. earlier reports suggest that similar low-fat percentages from different fruit samples viz., banana $(0.3 \%)$, apple $(0.4 \%)$, grape, mango, and papaya with trace (Ogbuagu and Agu, 2008). Passion fruit with $1.20 \%$ and highest recorded $17 \%$ from avocado fruits. These observations are under Syzgium caryophyllatum (Kasunmala et al., 2021).

The extensive contributors to the antioxidant capacity of grains, fruits, and vegetables are due to the scientific interest in phenolic compounds as chemo-precautionary and therapeutic agents against several chronic diseases was stimulated in the late 1990s (SánchezRangel et al., 2013), these results are in agreements with (LopezVidana et al., 2017). Isoquercetin-a flavonoid glycoside was successfully isolated from methanolic stem and leaf extract of Diplocyclos palmatus and it has been under evaluation for the treatment of thromboembolism of vein in colorectal cancer, renal cell carcinoma and kidney cancer (Shashikala et al., 2019).

Drying methods influence qualitative and quantitative aspects of phytoconstituents for better retention of their activity (Irondi et al., 2013; Devi et al., 2019). Antioxidant properties are also used for potential therapeutic effects (Modi et al., 2018). Natural antioxidant phytoconstituents have a variety of in vivo effects. They may be responsible for the de novo synthesis of antioxidants or may also generate new mechanisms of antioxidants (Gadade and Patil, 2019). In contrast, earlier reports have shown that hot air oven-dried at $50^{\circ} \mathrm{C}$ for $72 \mathrm{~h}$, powdered methanolic Soxhlet extracts have shown highest radical scavenging activity, suggesting temperature has favored for effective radical scavenging activity (Attar and Ghnae, 2017). Here, the superoxide anion is a reduced form that begins oxidation but scavenges gradually, and several pathophysiological processes (Chou et al., 2009).

\section{Conclusion}

The present study is an effort to find out the impact of temperature on nutritional quality and bioactivity of phytoconstutients of the selected fruits; two different drying methods have been used. The difference in the physicochemical distinction is considerably diverse due to agro-climatic condition, species, and time of final harvesting stages. The $\mathrm{pH}$ of the fruit was acidic, color development in fruit is a result of anthocyanins, which have a high antioxidant capacity, ${ }^{\circ}$ Brix levels of fruit could have been influenced by storage temperature.

Ethanolic cold macerated with a slight difference in case of similar treatments both with Soxhlet extracts. This indicates that the selected samples have a good quantity of phenolics both bound and free forms. The obtained total protein content also supports the presence of total phenolic content. In comparison with results of TFC also supports that some of the bound forms of phenolics have been released at the time of estimation. Temperature and solvents have been favored for obtaining the highest percentage. For the first time bioactivity, assay viz., hydrogen peroxide, reducing potential and NBT assay for selected fruits have been tested and overall bioactivity assay results reveal that TFC, ABTS, ${ }^{++} \mathrm{H}_{2} \mathrm{O}_{2}$, and NBT assay, ethylacetate Soxhlet extracts of both the fruits have shown very good antioxidant potency. The selected plant fruits possess a good amount of nutrients as well as showed bioactivity, however; further experiments are ongoing for the estimation of minerals, other phytoconstituents, isolation, and characterization of the specific bioactive compound responsible for the confirmation of bioactivity.

\section{Conflicts of interest}

The authors declare no conflicts of interest relevant to this article.

\section{References}

Ambawat, S. and Khetarpaul, N. (2018). Comparative assessment of antioxidant, nutritional and functional properties of soybean and its by-product okara. Ann. Phytomed., 7(1):112-118.

Attar, U. A. and Ghane, S. G. (2017). Phytochemicals, antioxidant activity and phenolic profiling of Diplocyclos palmatus (L.) C. Jeffery. Int. J. Pharm. Sci., 9(4):101-6.

Bates, D.M.; Robinson, R.W. and Jeffery, C. (1990). Biology and utilization of the Cucurbitaceae, Cornell University Press, Comstock publishing associates., pp:318-324.

Bhavani, M. B. (2013). Investigation on bioactive potential of medicinally important wild Cucurbitaceae plants. Ph.D.Thesis, University of Mysore, Mysore.

Blessing, A. C.; Ifeanyi, U. M. and Chijioke, O. B. (2011). Nutritional evaluation of some Nigerian pumpkins (Cucurbita spp.). Fruit, Veg. Cereal Sci. Biotech., 5(2):64-71.

Brand-Williams, W.; Cuvelier, M. E.and Berset, C. (1995). Use of a free radical method to evaluate antioxidant activity. LWT - Food Sci. Technol., 28(1):25-30.

Chou, H.J.; Kuo,J.T.; Lin, E.S.; Chou, C.H.S.J.; Kuo, J.; Lin,E.; Chou, H.J.; Kuo, J.T.; Lin, E.S,; Chou, J. and Kuo,T. (2009). Comparative antioxidant properties of water extracts from different parts of Beef steak plant (Perilla frutescens). J. Food Drug Anal., 17(6):489-496.

Davey, K. R. (1989). A predictive model for combined temperature and water activity on microbial growth during the growth phase. J. Appl. Bacterial., 67(5):483-488. 
De Monte, C.; Carradori,S.; Chimenti,P.; Secci,D.; Mannina,L.; Alcaro, F.; Petzer,A.; N'Da, C.I.; Gidaro, M.C.; Costa,G.; Alcaro,S. and Petzer, J. P. (2014). New insights into the biological properties of Crocus sativus L.: Chemical modifications, human monoamine oxidases inhibition and molecular modeling studies. Eur. J. Med. Chem., 82:164-171.

Desai, B. B. and Salunkhe, D. K. (1991). Fruits and vegetables. In foods of plant origin., 301-412. Springer, Boston, MA.

Devi, C. B.; Bains, K. and Kaur, H. (2019). Effect of drying procedures on nutritional composition, bioactive compounds and antioxidant activity of wheatgrass (Triticum aestivum L). J. Food Sci. Technol., 56(1):491-496.

Frazier, W.S. and Westhoff, D.C. (1978). Food Microbiology, 3 rd edition, McGraw Hill, New York.

Gadade, J. P. and Patil, S. A. (2019). Phytochemical paradigm, antioxidant status and their correlation in Rotheca serrata (L.) Steane and Mabb. Ann. Phytomed., 8(2):156-166.

Gelderman, K. A.; Hultqvist, M.; Olsson, L. M.; Bauer, K.; Pizzolla, A.; Olofsson, P. and Holmdahl, R. (2007). Rheumatoid arthritis: The role of reactive oxygen species in disease development and therapeutic strategies. Antioxid. Redox Signal., 9(10):1541-1567.

Gil, M. I.; Tomás-Barberán, F. A.; Hess-Pierce, B. and Kader, A. A. (2002) Antioxidant capacities, phenolic compounds, carotenoids, and vitamin $\mathrm{C}$ contents of nectarine, peach, and plum cultivars from California. J. Agric. Food Chem., 50(17):4976-4982.

Gupta, P. and Wagh, R. D. (2014). A review on morphology, phytochemistry, pharmacology and folk-lore uses of Diplocyclos palmatus (L.) Jeffry. Int. J. Pharm. Life Sci., 5:3622-3626.

Halliwell, B. and Gutteridge, J.M. (1984). Oxygen toxicity, oxygen radicals, transition metals and disease. Biochem. J., 219(1):1-14.

Harborne, J. B. (1973). Phenolic compounds, In phytochemical methods. pp:33-88.

Harbourne, N.; Marete, E.; Jacquier, J. C. and O'Riordan, D. (2009). Effect of drying methods on the phenolic constituents of meadowsweet (Filipendula ulmaria) and willow (Salix alba). LWT: Food Sci. Technol., 42(9):1468-1473.

Hayat, I.; Ahmad, A.; Masud, T.; Ahmed, A. and Bashir, S. (2014). Nutritional and health perspectives of beans (Phaseolus vulgaris L.): An overview. Crit. Rev. Food. Sci. Nutr., 54(5):580-592.

Horwitz, W. and Latimer, G.W. AOAC, (2006). Official methods of analysis of AOAC international (18th ed.), Association of Official Analytical Chemists, Gaithersburg, USA

Hossain, M. B.; Barry-Ryan, C.; Martin-Diana, A.B. and Brunton, N. P.(2010). Effect of drying method on the antioxidant capacity of six Lamiaceae herbs. Food Chem., 123(1):85-91.

Jiménez, N.; Carrillo-Hormaza, L.; Pujol,A.; Álzate, F.; Osorio, E. and Lara-Guzman, O. (2015). Antioxidant capacity and phenolic content of commonly used anti-inflammatory medicinal plants in Colombia Ind. Crops. Prod., 70:272-279.

Kasunmala, I. G. G.; Navarathne, S. B., and Wickramasinghe, I. (2021). Effect of drying methods on antioxidant activity of Syzygium Caryo phyllatum (L.) fruit pulp. Int. J. Fruit Sci., 21(1):634-644.

Kokate, C.K.; Purohit, A.P. and Gohkale, S.B. (1993). Pharmacognosy. In: Terpenoids, (21st ed), Nirali Prakashan, Pune, pp:377-378.

Kumar, H. and Totawar, P. (2015). Rationale behind uses of medicinal plant by gond tribe of Sironcha Tehsil, District- Gadchiroli, M.S., India. Int. J. Res. Biosci. Agric. Techn., 1:43-47.
López-Vidaña, E. C.; Pilatowsky Figueroa, I.; Cortés, F. B.; Rojano, B. A. and Navarro Ocaña, A. (2017). Effect of temperature on antioxidant capacity during drying process of mortiño (Vaccinium meridionale Swartz). Int. J. Food Prop., 20(2):294-305.

Mabberley, D. J. (1997). The plant book: A portable dictionary of the vascular plants, Cambridge University Press, Cambridge, New York, Melbourne, pp:233.

Metri, S.; Singh, R.P. and Shah, M. (2019). Isolation and identification of isoquercetin: A flavonoid from Bryonia laciniosa Linn., Int. J. Adv. Res., 7:780-786.

Modi, C. M.; Ladumor, V. C.; Patel, U.D.; Patel, H. B.; Solanki, S. L. and Bhadarka, D. H. (2018). Phytochemical analysis and comparative study of in vitro free radical scavenging activity of different extracts of leaves of Abrus precatorius L. Ann. Phytomed., 7(2):133-137.

Mosaddik, M. A. and Haque, M. E. (2003). Cytotoxicity and antimicrobial activity of goniothalamin isolated from Bryonopsis laciniosa. Phytotherapy Research: An International Journal Devoted to Pharmacological and Toxicological Evaluation of Natural Product Derivatives, 17(10):1155-1157.

Njoroge, G. N. and Newton, L. E. (1994). Edible and poisonous species of Cucurbitaceae in the Central Highlands of Kenya, East Afr. Nat. Hist., 83(2):101-115.

Nonga, H. E.; Simforian, E. A. and Ndabikunze, B. K. (2014). Assessment of physicochemical characteristics and hygienic practices along the value chain of raw fruit juice vended in Dar es Salaam City, Tanzania. J. Health Res., 16(4):269-79.

Ogbuagu, M. N. and Agu, B. (2008). Fruit nutritive composition of Maesobotrya barteri, an under-exploited tropical African tree. Fruits, 63(6):357-361.

Oyaizu, M. (1986). Studies on products of browning reaction antioxidative activities of products of browning reaction prepared from glucosamine. Jpn. J. Nutr., 44(6):307-315.

Packer, J.; Brouwer, N.; Harrington, D.; Gaikwad, J.; Heron, R.; Elders, Y. C.; Ranganathan,S.; Vemulpad,S. and Jamie, J. (2012). An ethnobotanical study of medicinal plants used by the Yaegl Aboriginal community in northern New South Wales, Australia. J. Ethnopharmacol., 139(1):244-255.

Puranik, V.; Chauhan, D. K.; Mishra, V. and Rai, G. K. (2012). Effect of drying techniques on the physicochemical and bioactive components of selected medicinal herbs. Ann. Phytomedicine., 1(2), 23-29.

Purvis, A. C. (1993). Effects of short-term CA storage on peach quality. Hort. Science, 28(4):277D-277.

Renner, S. S. and Pandey, A. K. (2013). The Cucurbitaceae of India: Accepted names, synonyms, geographic distribution, and information on images and DNA sequences. Phyto. Keys, 20:53-118.

Ruch, R. J.; Crist, K. A. and Klaunig, J. E. (1989). Effects of culture duration on hydrogen peroxide-induced hepatocyte toxicity Toxicol. Appl. Pharmacol., 100(3):451-464.

Sachindra, N. M.; Airanthi, M. K. W. A.; Hosokawa, M. and Miyashita, K. (2010). Radical scavenging and singlet oxygen quenching activity of extracts from Indian seaweeds. J. Food Sci. Technol., 47(1):94-99.

Sakanaka, S.; Tachibana, Y. and Okada, Y. (2005). Preparation and antioxidant properties of extracts of Japanese persimmon leaf tea (Kakinohacha). Food Chem., 89(4):569-575 
Sánchez-Rangel, J. C.; Benavides, J.; Heredia, J. B.; Cisneros-Zevallos, L. and Jacobo-Velázquez, D. A. (2013). The folin - Ciocalteu assay revisited: Improvement of its specificity for total phenolic content determination. Int. J. Food Prop., 5(21):5990-5999.

Singh, V. and Malviya, T. (2006). A non-ionic glucomannan from the seeds of an indigenous medicinal plant: Bryonia lacinosa. Carbohydr. Polym., 64(3):481-483.

Singleton, V. L. and Rossi, J. A. (1965). Colorimetry of total phenolics with phosphomolybdic phosphotungstic acid reagents. AJEV., 16(3):144158

Sun, Y.; Shen, Y.; Liu, D. and Ye, X. (2015). Effects of drying methods on phytochemical compounds and antioxidant activity of physiologically dropped un-matured citrus fruits. LWT: Food Sci. Technol., 60(2): $1269-1275$

Thorat, P. P.; Sawate, A.R.; Kadam, S.M. and Patil, B.M. (2018). Effect of drying on the phytochemical composition of lemongrass (Cymbopogon citratus (DC.) Stapf) powder. Ann. Phytomed., 7(2):183-188.

Tripathy, P. K.; Kumar, S. and Jena, P. K. (2013). Diversity and ethnobotanical assessment of some wild cucurbits of Similipal Biosphere Reserve forest, Odisha, India. Int. J. Pharm. Sci. Res., pp:5430-5437
Untalan, M. K. C.; Perez, I. F. R.; Escalona, G; De Gusman, L. and Lumanglas, R. (2015). Proximate analysis and antioxidant properties of selected fruits in Batangas. Asia Pac. J. Multidiscip. Res., 3(4):41-45.

Venketeshwer, R.(2012). Phytochemicals: A global perspective of their role in nutrition and health. Intechopen., Janeza trdine9, 51000 Rijeka, Croatia, pp:6-7.

Wang, J.; Yang, X. H.; Mujumdar,A. S.; Wang, D.; Zhao, J. H.; Fang, X. M.; Zhang,Q.; Xie, L.; Gao, Z.J.and Xiao, H. W. (2017). Effects of various blanching methods on weight loss, enzymes inactivation, phytochemical contents, antioxidant capacity, ultrastructure and drying kinetics of red bell pepper (Capsicum annuиm L.). LWT, 77:337-347.

Williams, V. M.; Filippova, M.; Filippov, V.; Payne, K. J. and Duerksen-Hughes, P. (2014). Human papillomavirus type 16 E6* induces oxidative stress and DNA damage. Virol. J., 88(12):6751-6761.

Zengina, G.; Nithiyanantham, S.; Locatelli, M.; Ceylana, R.; Uysala, S.; Aktumseka, A.; Selvie, P. K. and Maskovic, P.(2016). Screening of in vitro antioxidant and enzyme inhibitory activities of different extracts from two uninvestigated wild plants: Centranthus longiflorus subsp. longiflorus and Cerinthe minor subsp. Auriculata. Eur. J. Integr. Med., 8(3):286292.

Ramya Banave Rajashekar, Nakkarike Manjubatta Sachindra, Naveen Shivanna and Leelavathi Sakriyanaik (2021). Effect of drying methods on proximate analysis and antioxidant activities of ripe and unripe fruits of Diplocyclos palmatus (L.) C. Jeffery. Ann. Phytomed., 10(2):398-408. http://dx.doi.org/10.21276/ap.2021.10.2.53 